International Journal of Sustainable Agricultural Research

2021 Vol. 8, No. 3, pp. 122-133.

$\operatorname{ISSN}(e): 2312-6477$

$\operatorname{ISSN}(p): 2313-0393$

DOI: 10.18488/journal.70.2021.83.122.133

(C) 2021 Conscientia Beam. All Rights Reserved.

check for
updates

\title{
EFFECT OF LAND USE AND SLOPE POSITION ON INFILTRATION CHARACTERISTICS ON SANDSTONE-DERIVED SOILS OF SOUTHERN NIGERIA
}

Utin, U. E.

\author{
Department of Soil Science and Land Resources Management, University of \\ Uyo, Uyo, Nigeria. \\ Email:utibeutin@uniuyo.edu.ng Tel:+2348085827104
}

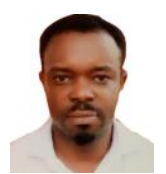

\section{Article History \\ Received: 17 February 2021 Revised: 22 March 2021 \\ Accepted: 28 April 2021 \\ Published: 24. May 2021}

Keywords

Soil physical properties

Infiltration

Land use

Vegetation

Continuous cultivation

Slope position

Downslope

Sandstone-derived soils.

\section{ABSTRACT}

A study of some soil properties that influence infiltration under different land use types and slope positions in sandstone-derived soils was carried out in Akwa Ibom State, Southern Nigeria. Soil samples were collected in triplicate for laboratory analyses and infiltration tests were conducted using the double ring infiltrometer method. Analysis of variance, correlation and regression analyses were used to assess the data Oil Palm Plantation and Fallow Land increased the organic matter content of the soil, reduced bulk density, increased the soil porosity and aggregate stability over Continuously Cultivated Land. Downslope soil movement caused the upper slopes to lose their clay and organic matter to the middle and lower slope soils. Initial infiltration rate, final infiltration rate, cumulative infiltration, sorptivity and transmissivity varied highly across the studied locations but were not significantly $(\mathrm{P} \leq 0.05)$ affected by land use, slope position and their interactions. Apparently higher infiltration rates were observed in all slope positions under Oil Palm Plantation and Fallow Land as a result of their apparently higher clay contents, total porosity, mean weight diameter, saturated hydraulic conductivity and organic matter contents over those of Continuously Cultivated Land. Heavier organic matter input will help to modify the upper slope soils for increased infiltration rates. Plantation agriculture should be adopted and continuous cultivation discouraged to increase water infiltration on sloppy terrains of the study area.

Contribution/Originality: This study is one of very few studies which have investigated the combined effect of land use and slope position on infiltration characteristics and has demonstrated that infiltration tend to increase towards the lower slope position of vegetated lands compared to upper slopes rendered bare by continuous cultivation.

\section{INTRODUCTION}

Infiltration is a physical phenomenon and a major process of the hydrologic cycle occurring at the soilatmosphere interphase (Mbagwu, 1995). It is the process of water entry into the soil, generally by downward flow from the soil surface into the soil profile (Hillel, 2004; Lal, 1981) and through which water is made available in the soil for the survival and growth of plants and soil organisms. It is a key to soil and water conservation (Ogban et al., 2012) because the amount of water infiltrating the soil surface has a direct influence on the magnitude of surface runoff, erosion, and the recharge of both soil and ground water (Liu et al., 2011).

Factors that control infiltration rates include soil properties that strongly affect hydraulic conductivity, diffusivity and water holding capacity and these are soil texture, structure, composition, and degree of compaction, which also influence soil matric forces and pore space (Turner, 2006). While there are standard values of infiltration 
rates available for different soil types, factors such as land and slope positions cover also have a documented influence on infiltration rates. This makes infiltration highly variable across spatiotemporal scales (Soderberg, 2015). Generally, infiltration is highly variable because all factors that affect infiltration are spatially and temporally heterogeneous (Freeze \& Cherry, 1979). This high variability and measurement uncertainties of infiltration make generalization of point data to larger areas dubious (Youngs, 1991) thus the need for continuous site-specific infiltration studies.

Previous studies have reported the effects of different land use types on infiltration characteristics of soils. Osuji, Okon, Chukwuma, and Nwarie (2010) studied arable crop land, bush fallow, continuously cultivated land and pineapple orchard and found fallow land to have highest infiltration rates. Ogban and Utin (2015) studied oil palm plantation, fallowed land and cultivated land and found no significant $(\mathrm{P} \leq 0.05)$ differences in initial infiltration $\left(i_{0}\right)$, sorptivity (S) and transmissivity (A) among the land use types. Significant $(\mathrm{P}<0.05)$ differences were observed in the final infiltration rate $\left(i_{\mathrm{f}}\right)$ in the order OPP $>$ FLL $>$ CFL. Cumulative infiltration (I) was similar in FFL and CFL but significantly lower than the value obtained in OPP.

In the same vein, slope position has been observed by many authors to affect water infiltration into soils. Cerdia (1996) reported slope position as one of the factors that determine infiltration rates in Southeast Spain. In their study of landscape position effect on selected soil physical properties in south-central Iowa, Guzman and Al-Kaisi (2011) found infiltration rates to be much greater in the toe-slope than the summit. Shukla, Lal, and Unkefer (2003) reported that among the parameters related to infiltration, it was only sorptivity that was significantly affected by slope position. Conversely, Yimer, Messing, Ledin, and ABdelkadir (2008) found no significant $(\mathrm{P} \leq 0.05)$ differences in infiltration characteristics across different slope positions.

Akwa Ibom State, located in the Southern Nigeria, has a variety of landforms and parent materials such as coastal plan sands which overs over $80 \%$ of the state. Others are sandstone, beach ridge sands and alluvial deposits. Sandstones are found in Ini, Ikono and part of Itu areas of the State. They have lands of enchanting steep-sided hills, valleys and sharp-crested sandstone ridges separated by deep valleys and these lands are being put to a variety of agricultural uses. The present study is therefore aimed at determining the effect of land use and slope position on infiltration characteristics on sandstone soils in Akwa Ibom State, Nigeria, the knowledge of which will help in making proper soil management decisions aimed at engendering soil health and productivity in the study area.

\section{MATERIALS AND METHODS}

\subsection{The Study Area}

The study was conducted in Ini area of northern Akwa Ibom State, which bears soils underlain by the sandstone parent material. Akwa Ibom State lies between latitudes $4^{\circ} 30^{\prime}$ and $5^{\circ} 30^{\prime} \mathrm{N}$ and longitudes $7^{\circ} 27^{\prime}$ and $8^{\circ}$ $27^{\prime}$ E. It is located in the hot humid tropics, with a uniform climate which varies slightly from the coastal areas in the south to the north. The area experiences the wet season which takes place between April and October and the dry season which occurs between November and March. Rainfall ranges from about $3000 \mathrm{~mm}$ along the coast to $2000 \mathrm{~mm}$ in northern fringes. The rainfall is bimodal with peaks in July and September (Petters, Adighije, Essang, \& Ekpo, 1989). Relative humidity varies between 75 and $90 \%$ with an average of $70 \%$. The mean annual temperature ranges from $26^{\circ} \mathrm{C}$ to $28^{\circ} \mathrm{C}$.

Alluvial sands and clays cover over 80 percent of the state and constitute the Benin Formation, otherwise known as the Coastal Plain Sands. A belt of shale associated with sandstone and limestone stretches from the north to the north-east of the State. The soils are derived from the sandy parent materials and are highly weathered and dominated by low activity clay minerals (Petters et al., 1989). The soils have low contents of organic matter, base status and water storage capacity, and are highly susceptible to accelerated erosion and degradation (Enwezor, Udo, \& Sobulo, 1981; Petters et al., 1989). 
The native tropical rainforest vegetation has been almost completely replaced by secondary forest of predominantly wild oil palm trees of various densities of coverage, and woody shrubs such as Chromolaena odorata (siam weed) and various grass undergrowth. The predominant land use in the area as in most of the south-east is the cropping-bush fallow-cropping closed system and the major food crops grown are yams, cassava, maize and vegetables.

\subsection{Field Methods}

Soil samples were collected in triplicates based on nine combinations of land use and slope position as follows: continuously cultivated farmland (CFL) + upper slope (US), CFL + middle (MS), CFL + lower slope (LS), fallow land (FLL) + US, FLL+MS, FLL+LS, oil palm plantation (OPP) + US, OPP + MS and OPP + LS. This gave a total of twenty-seven (27) observation points.

At each observation point, three random auger samples were collected at the depth of $0-20 \mathrm{~cm}$. The samples were bulked and put into a polythene bag and labelled appropriately and were used for particle size and chemical analyses. Core samples were also collected using metal cylinders measuring $7.2 \mathrm{~cm}$ long and $6.8 \mathrm{~cm}$ internal diameter. The soil samples were held in the cylinders with cloth and rubber band and were used for the determination of saturated hydraulic conductivity and bulk density. Soil samples used in the determination mean weight diameter (MWD) was collected using spade and were carefully protected from structural degradation.

Infiltration was also measured at each observation point using the double ring infiltrometer method (Food and Agriculture Organization, 1979). The infiltrometer, with an outer ring of $55 \mathrm{~cm}$ diameter and an inner ring of 30 $\mathrm{cm}$ diameter was driven into the soil with the aid of a driving plate to a depth of $10 \mathrm{~cm}$. The soil surface within the rings was covered with leaves to protect against direct water splash which could disrupt the surface structure and alter the infiltration results. Water was added to a depth of $15 \mathrm{~cm}$ and infiltration or the one-dimensional vertical flow of water was measured with aid of a plastic ruler in the inner ring while the outer ring served as a buffer against lateral flow of water.

Measurements were taken only from the inner ring at 1 minute till a cumulative time of 10 minutes was reached, then at an interval of 2 minutes till a cumulative time of 20 minutes, then at every 5 minutes till a cumulative time of 50 minutes was reached and then at every 10 minutes till the end of the test at cumulative time of 120 minutes. The data generated were used to calculate the initial infiltration rate (io), the final infiltration rate $\left(i_{\mathrm{f}}\right)$ and cumulative infiltration. Sorptivity $(S)$ and transmissivity $(\mathrm{A})$ were determined using the mathematical and physical analysis of the infiltration process developed by Philip (1957) as follows:

$\mathrm{I}=\mathrm{S} t^{1 / 2}+\mathrm{At}$

where,

$\mathrm{I}=$ cumulative infiltration or equivalent depth of water $(\mathrm{cm}), \mathrm{S}=$ sorptivity, $\mathrm{A}=$ transmissivity, $t=$ time. The constants $\mathrm{A}$ and $\mathrm{S}$ were determined by plotting a graph of $\mathrm{d} i / \mathrm{d} t$ against $t^{1 / 2} ; \mathrm{A}$ is the intercept and $\mathrm{S}$ is the slope.

\subsection{Laboratory Methods}

Soil analyses were carried out at the University of Uyo Soil Laboratory. Particle size analysis was determined using the Bouyoucos hydrometer method (Dane \& Topp, 2002). Bulk density and saturated hydraulic conductivity were determined as described in Dane and Topp (2002). Total porosity was calculated from bulk density value. Soil organic carbon was determined using the Walkley and Black wet oxidation method (Nelson \& Sommers, 1996). Organic matter was calculated from values of organic carbon. Mean weight diameter (MWD) was calculated after the determination of aggregate size distribution with 4, 2, 1, 0.5 and >0.25 mm sieve size (Kemper \& Rosenau, 1986). Mean weight diameter (MWD) of water stable aggregates was therefore calculated thus: 
where $X i$ is the mean diameter of the $i$ th sieve size and $W i$ is the proportion of the total mass of aggregates in the ith fraction.

\subsection{Data Analysis}

Data were assessed using the analysis of variance at $95 \%$ confidence level and mean separated using the least significant different (LSD). Associations between soil properties and infiltration characteristics were determined using correlation analysis, while the simple linear regression was used to find the relationship between cumulative infiltration and soil properties. Data analyses were achieved with the aid of the Genstat Discovery Edition and IBM SPSS Statistical packages.

\section{RESULTS AND DISCUSSION}

\subsection{Effect of Land Use on Some Soil Properties}

Effect of land use on some soil properties are presented in Table 1. The results show that continuous farmland $(\mathrm{CFL})$ contained significantly $(\mathrm{P} \leq 0.05)$ higher coarse sand than fallow land (FLL) and oil palm plantation (OPP), while the reverse was the case with fine sand and clay contents. The higher concentration of coarse sand in CFL may be due to the frequent tillage, which may have disrupted the structural integrity of the soil and accelerated surface runoff and soil erosion (Al-Kaisi, 2019) through which most of the fine soil particles were lost, leaving the coarse sand to dominate. Conversely, the FLL and OPP experienced no frequent structural degradation, this reduced the ease of detachment and movement of fine sand and clay particles when compared with CFL.

Table-1. Effect of land use and slope position on soil properties.

\begin{tabular}{|c|c|c|c|c|c|c|c|c|c|}
\hline & CS & FS & Silt & Clay & BD & $\overline{T P}$ & MWD & Ksat & $\mathrm{OM}$ \\
\hline & \multicolumn{4}{|c|}{$\mathrm{g} \mathrm{kg}^{-1} \longrightarrow$} & $\mathrm{Mg} \mathrm{m}^{-3}$ & $\mathrm{M}^{3} \mathrm{~m}^{-3}$ & $\mathrm{Mm}$ & $\mathrm{cm} \mathrm{h}^{-1}$ & $\%$ \\
\hline CFL & 651 & 190 & 66 & 93 & 1.58 & 0.40 & 0.65 & 4.51 & 2.49 \\
\hline OPP & 614 & 214 & 59 & 113 & 1.45 & 0.45 & 1.18 & 8.17 & 3.12 \\
\hline Sig & 0.00 & 0.00 & 0.35 & $<.001$ & $<.001$ & $<.001$ & $<.001$ & 0.01 & $<.001$ \\
\hline
\end{tabular}

Bulk density observed in CFL was significantly $(\mathrm{P} \leq 0.05)$ higher than those of FLL and OPP Table 1. This could be attributed to the fact that management practice involved in CFL reduced soil cover, organic matter content, destroyed soil structure and promoted soil compaction (USDA, 2014) as against the cases of FLL and OPP that witnessed no such frequent disturbances. The contents of coarse sand, fine sand, clay and bulk density observed in FLL and OPP were not significantly $(\mathrm{P} \leq 0.05)$ different.

In the cases of total porosity, mean weight diameter of water stable aggregates, saturated hydraulic conductivity and organic matter content Table 1 FLL and OPP were similar but significantly $(\mathrm{P} \leq 0.05)$ higher than what were observed in CFL. The increased input of vegetal debris and absence of soil disturbance which characterize soils of FLL and OPP over that of CFL were responsible for these results. The increased input of vegetal debris improved the organic matter status of soils (Bot \& Benites, 2005) under FLL and OPP. The reduced bulk density, increased total porosity, soil aggregation and saturated hydraulic conductivity in FLL and OPP is suggestive of improved soil structural conditions (Blanco \& Lal, 2008; Carrizo, Alesso, Cosentino, \& Imhoff, 2014) under FLL and OPP as opposed to CFL. Cooperband (2002) had reported that organic matter, despite its small percentage in soil is the foundation of a healthy and productive soil. Other research works agree that organic matter 
reduces bulk density, increases total porosity (Chaudhari, Ahire, Ahire, Chkravarty, \& Maity, 2013) improves soil aggregation as one of the main abiotic binding agents (the other being clay) in the formation and stabilization of aggregates (Chenu, Le Bissonnais, \& Arrouays, 2000; Duchicela et al., 2012; Liu et al., 2017; Portella, Guimarães, Feller, Fonseca, \& Tavares Filho, 2012).

\subsection{Effect of Slope Position on Some Soil Properties}

Effect of slope position on coarse sand (CS), fine sand (FS), silt, bulk density (BD), total porosity (TP), mean weight diameter of water stable aggregates (MWD) and saturated hydraulic conductivity ( $K_{\text {sat }}$ ) were not significantly $(\mathrm{P} \leq 0.05)$ affected by slope position Table 2. Previous research works have equally reported nonsignificant difference in sand content (Yeshaneh, 2015) bulk density and total porosity (Moges \& Holden, 2008) and saturated hydraulic conductivity (Rivera, 2010) among different slope positions.

Table-2. Effect of slope position on some soil properties.

\begin{tabular}{|c|c|c|c|c|c|c|c|c|c|}
\hline & CS & FS & Silt & Clay & BD & TP & MWD & Ksat & $\mathbf{O M}$ \\
\hline & 4 & $\square$ & 1 & $\longrightarrow$ & $\mathrm{Mg} \mathrm{m}^{-3}$ & $\mathrm{M}^{3} \mathrm{~m}^{-3}$ & $\mathrm{Mm}$ & $\mathrm{cm} \mathrm{h}^{-1}$ & $\%$ \\
\hline US & 635 & 210 & 56 & 99 & 1.51 & 0.43 & 1.02 & 7.95 & 2.72 \\
\hline MS & 627 & 208 & 56 & 108 & 1.49 & 0.44 & 0.99 & 7.06 & 2.96 \\
\hline $\mathrm{LS}$ & 606 & 211 & 69 & 114 & 1.46 & 0.45 & 0.98 & 6.65 & 3.09 \\
\hline Sig & 0.07 & 0.94 & 0.10 & 0.02 & 0.20 & 0.20 & 0.66 & 0.61 & 0.02 \\
\hline$L S D_{(0.05)}$ & $n s$ & $n s$ & $n s$ & 10 & $n s$ & $n s$ & $n s$ & $n s$ & 0.25 \\
\hline
\end{tabular}

Note: CS - coarse sand, FS - fine sand, BD - bulk density, TP - total porosity, MWD - mean weight diameter, Ksat - saturated hydraulic conductivity, OM - organic matter, ns - not significant.

Clay was significantly $(\mathrm{P} \leq 0.05)$ affected by slope position with LS having the highest clay content, which was equal with that of MS but significantly $(\mathrm{P} \leq 0.05)$ higher than that of US. A similar trend as that of clay was observed with organic matter Table 2. The higher clay and organic matter contents in middle and lower slopes compared with upper slope can be linked to the loss of soil and movement from the upslope regions by runoff and eventual deposition at the middle and lower slope regions. Jenny (1994) mentioned slope as a factor influencing the extent of soil loss due to erosion. Soils can also be slowly moved downslope through gravitational force (Blanco \& Lal, 2008) this is called creep (Lal, 1981). When soils particles are detached and transported from their original place, they move with materials such as organic matter, clay, nutrients, etc. and are deposited elsewhere. This is possibly the reason for the higher content of clay and organic matter at the MS and LS positions compared with the US position. Yeshaneh (2015) similarly reported highest clay content at the lower and middle slopes than at the upper slope while Bot and Benites (2005) asserted that organic matter accumulation is often favoured at the lower slope regions.

\subsection{Interactive Effect of Land Use and Slope Position on Some Soil Properties}

The influence of land use on studied soil properties were greater than that of slope position while the interactive effect of both (land use and slope position) did not have significant $(\mathrm{P} \leq 0.05)$ effects on the studied soil properties Table 3. This means that no particular slope position under the studied land use types was quite different from others in terms of the soil properties studied. However, apparent differences in clay, BD, TP, MWD, Ksat and OM were observed between in different slope positions of CFL, FLL and OPP Table 3. The least of clay contents, TP, MWD, Ksat and OM were observed in the slope positions of CFL compared to those of FLL and OPP. This is suggestive of the low structural stability of soils at all slope positions of CFL as compared with those of OPP and FLL. 
Table-3. Interactive effect of land use and slope position on some soil properties.

\begin{tabular}{|c|c|c|c|c|c|c|c|c|c|c|}
\hline & & $\mathrm{CS}$ & FS & Silt & Clay & BD & TP & MWD & Ksat & OM \\
\hline & & & $-g$ & -1 & $\rightarrow$ & $\mathrm{Mg} \mathrm{m}^{-3}$ & $\mathrm{M}^{3} \mathrm{~m}^{-3}$ & $\mathrm{Mm}$ & $\mathrm{cm} \mathrm{h}^{-1}$ & $\%$ \\
\hline \multirow[t]{3}{*}{ CFL } & US & 660 & 199 & 53 & 88 & 1.62 & 0.39 & 0.65 & 5.14 & 2.36 \\
\hline & MS & 642 & 189 & 72 & 97 & 1.57 & 0.41 & 0.67 & 4.07 & 2.59 \\
\hline & $\mathrm{LS}$ & 652 & 181 & 72 & 95 & 1.57 & 0.41 & 0.65 & 4.32 & 2.53 \\
\hline \multirow[t]{3}{*}{ FLL } & US & 607 & 229 & 55 & 108 & 1.44 & 0.46 & 1.20 & 8.19 & 3.01 \\
\hline & MS & 626 & 220 & 43 & 110 & 1.42 & 0.46 & 1.19 & 8.35 & 3.06 \\
\hline & $\mathrm{LS}$ & 577 & 229 & 69 & 125 & 1.41 & 0.47 & 1.11 & 10.39 & 3.39 \\
\hline \multirow[t]{3}{*}{ OPP } & US & 638 & 203 & 60 & 99 & 1.46 & 0.45 & 1.22 & 10.54 & 2.79 \\
\hline & MS & 614 & 216 & 52 & 118 & 1.47 & 0.45 & 1.13 & 8.75 & 3.23 \\
\hline & $\mathrm{LS}$ & 590 & 223 & 65 & 122 & 1.41 & 0.47 & 1.18 & 5.23 & 3.34 \\
\hline Sig. & & 0.27 & 0.41 & 0.31 & 0.42 & 0.76 & 0.76 & 0.77 & 0.25 & 0.48 \\
\hline$L S D_{(0.05)}$ & & $n s$ & $n s$ & $n s$ & $n s$ & $n s$ & $n s$ & $n s$ & $n s$ & $n s$ \\
\hline
\end{tabular}

\subsection{Effect of Land Use on Infiltration Characteristics}

Infiltration characteristics were not significantly $(\mathrm{P} \leq 0.05)$ affected by land use Table 4 but apparent considerations show that CFL had the lowest initial infiltration rate $\left(i_{\mathrm{o}}\right)$ of $0.61 \mathrm{~cm} \mathrm{~min}^{-1}$, lowest final infiltration rate $\left(i_{\mathrm{f}}\right)$ of $0.26 \mathrm{~cm} \mathrm{~min}^{-1}$, lowest cumulative infiltration $(\mathrm{I})$ of $30.59 \mathrm{~cm}$, lowest sorptivity (S) of $0.25 \mathrm{~cm} \mathrm{~min}^{-1 / 2}$ and lowest transmissivity (A) of $0.53 \mathrm{~cm} \mathrm{~min}^{-1}$. Infiltration characteristics of FLL were apparently next to those of CFL while those of OPP were the highest with values of $1.19 \mathrm{~cm} \mathrm{~min}^{-1}, 0.61 \mathrm{~cm} \mathrm{~min}^{-1}, 73.59 \mathrm{~cm}, 0.51 \mathrm{~cm} \mathrm{~min}^{-1 / 2} \mathrm{and} 1.00$ $\mathrm{cm} \mathrm{min}^{-1}$ for $i_{\mathrm{o}}, i_{\text {f, I, S }}$ and A, respectively. This apparent higher infiltration rates in OPP and FLL over CFL can be attributed to the significantly $(\mathrm{P} \leq 0.05)$ higher organic matter content observed in OPP and FLL than in CFL. The higher organic matter content may have reduced compaction and increased porosity (Cooperband, 2002) thus the increased infiltration of OPP and FLL soils over CFL soil in which continuous cultivation had burned up organic matter considerably, caused soil compaction and closure of pores (Gol \& Dengiz, 2008).

Table-4. Effect of land use on infiltration characteristics.

\begin{tabular}{|c|c|c|c|c|c|}
\hline & $i_{0}$ & $i_{\mathrm{f}}$ & \multirow{2}{*}{$\frac{\mathbf{I}}{\mathrm{cm}}$} & \multirow{2}{*}{$\begin{array}{c}\mathbf{S} \\
\mathrm{cm} \mathrm{min} \\
\min ^{-1 / 2}\end{array}$} & \multirow{2}{*}{$\frac{\mathrm{A}}{\mathrm{cm} \mathrm{min} \mathrm{min}^{-1}}$} \\
\hline & $\leftarrow$ & $\mathrm{cm} \mathrm{min}^{-1} \rightarrow$ & & & \\
\hline $\mathrm{CFL}$ & 0.61 & 0.26 & 30.59 & 0.25 & 0.53 \\
\hline FLL & 1.09 & 0.54 & 65.93 & 0.48 & 0.89 \\
\hline OPP & 1.19 & 0.61 & 73.59 & 0.51 & 1.00 \\
\hline Sig. & 0.17 & 0.09 & 0.08 & 0.32 & 0.26 \\
\hline$L S D_{(0.05)}$ & $n s$ & $n s$ & $n s$ & $n s$ & $n s$ \\
\hline
\end{tabular}

\subsection{Effect of Slope position on Infiltration Characteristics}

Table 5 presents the means of infiltration characteristics as affected by slope position. The respective mean values of $i_{0}, i_{\mathrm{f}}, \mathrm{I}, \mathrm{S}$ and A were $0.82 \mathrm{~cm} \mathrm{~min}^{-1}, 0.41 \mathrm{~cm} \mathrm{~min}^{-1}, 50.22 \mathrm{~cm}, 0.36 \mathrm{~cm} \mathrm{~min}^{-1 / 2}$ and $0.67 \mathrm{~cm} \mathrm{~min}^{-1}$ in the US soils; that of MS soils were $0.92 \mathrm{~cm} \mathrm{~min}^{-1}, 0.47 \mathrm{~cm} \mathrm{~min}^{-1}, 56.46 \mathrm{~cm}, 0.39 \mathrm{~cm} \mathrm{~min}^{-1 / 2}$ and $0.80 \mathrm{~cm} \mathrm{~min}^{-1}$ while those of LS were $1.15 \mathrm{~cm} \mathrm{~min}^{-1}, 0.53 \mathrm{~cm} \mathrm{~min}^{-1}, 63.43 \mathrm{~cm} \mathrm{~min}^{-1}, 0.49 \mathrm{~cm} \mathrm{~min}^{-1 / 2}$ and $0.94 \mathrm{~cm} \mathrm{~min}^{-1}$. The general trend of infiltration characteristics on the basis of slope position was LS > MS > US Table 5. This downslope increase in infiltration can be linked to the increase in organic matter which was also observed in that direction. In addition, bulk density reduction and increase in total porosity, though not significantly $(\mathrm{P} \leq 0.05)$ different among the different slope positions, were also observed downslope. The higher organic matter, lower bulk density and higher total porosity enhanced water infiltration (Bot \& Benites, 2005; USDA, 2014). $\leq$ 
Table-5. Effect of slope position on infiltration characteristics.

\begin{tabular}{|c|c|c|c|c|c|}
\hline & $i_{0}$ & $i_{f}$ & \multirow{2}{*}{$\begin{array}{c}\mathbf{I} \\
\mathrm{cm} \\
\end{array}$} & \multirow{2}{*}{$\begin{array}{c}\mathrm{S} \\
\mathrm{cm} \min ^{-1 / 2} \\
\end{array}$} & \multirow{2}{*}{$\begin{array}{c}\mathrm{A} \\
\mathrm{cm} \text { min }^{-1}\end{array}$} \\
\hline & \multicolumn{2}{|c|}{$\operatorname{cm} \min ^{-1} \rightarrow$} & & & \\
\hline US & 0.82 & 0.41 & 50.22 & 0.36 & 0.67 \\
\hline MS & 0.92 & 0.47 & 56.46 & 0.39 & 0.80 \\
\hline $\mathrm{LS}$ & 1.15 & 0.53 & 63.43 & 0.49 & 0.94 \\
\hline Sig & 0.56 & 0.77 & 0.79 & 0.77 & 0.65 \\
\hline$L S D_{(0.05)}$ & $n s$ & $n s$ & $n s$ & $n s$ & $n s$ \\
\hline
\end{tabular}

\subsection{Interactive Effect of Land Use and Slope Position on Infiltration Characteristics}

Soil infiltration characteristics were also not significantly $(\mathrm{P} \leq 0.05)$ affected by the interactive effect of land use and slope position Table 6. This means that no particular slope position under any of the studied land use types was quite different from the others in infiltration characteristics. Apparent considerations however showed CFL+US to have the lowest $i_{\mathrm{o}}\left(0.37 \mathrm{~cm} \mathrm{~min}^{-1}\right), i_{\mathrm{f}}\left(0.12 \mathrm{~cm} \mathrm{~min}^{-1}\right), \mathrm{I}(14.37 \mathrm{~cm}), \mathrm{S}\left(0.08 \mathrm{~cm}^{-1 / 2}\right)$ and $\mathrm{A}\left(0.55 \mathrm{~cm} \mathrm{mi}^{-1}\right)$. Generally, higher infiltration rates were observed in all slope positions under OPP and FLL compared to those of CFL. The apparent lower clay contents, total porosity, mean weight diameter, saturated hydraulic conductivity and organic matter contents observed in all slope positions of CFL could be attributed to excessive tillage and suppressed vegetation and may have been responsible for the lower infiltration (Bot \& Benites, 2005; USDA, 2014) observed in CFL than in OPP and FLL.

Infiltration characteristics in the study area were highly variable (>35\%) Table 6. The high variability in infiltration characteristics decreased their significance and confidence levels, thus the non-significant $(\mathrm{P} \leq 0.05)$ effect of land use and slope position on infiltration characteristics found in this study. Singh, Sihag, and Singh (2014) and Soderberg (2015) also reported high variability of infiltration characteristics. Freeze and Cherry (1979) attributed the high variability of infiltration to the spatial and temporal heterogeneity of factors that affect infiltration. Yimer et al. (2008) equally found no significant $(\mathrm{P} \leq 0.05)$ differences in infiltration capacity across different slope positions and land use types.

Table-6. Interactive effect of land use and slope position on infiltration characteristics.

\begin{tabular}{|c|c|c|c|c|c|c|}
\hline & & $i_{0}$ & $i_{\mathrm{f}}$ & \multirow{2}{*}{$\begin{array}{c}\text { I } \\
\mathbf{c m} \\
\end{array}$} & \multirow{2}{*}{$\begin{array}{c}\mathrm{S} \\
\mathrm{cm} \mathrm{min}^{-1 / 2}\end{array}$} & \multirow{2}{*}{$\frac{\mathrm{A}}{\mathrm{cm} \text { min }^{-1}}$} \\
\hline & & \multicolumn{2}{|c|}{ cm min min $^{-1} \rightarrow$} & & & \\
\hline \multirow[t]{3}{*}{$\mathrm{CFL}$} & US & 0.37 & 0.12 & 14.30 & 0.08 & 0.55 \\
\hline & MS & 0.73 & 0.29 & 34.34 & 0.34 & 0.63 \\
\hline & $\mathrm{LS}$ & 0.73 & 0.30 & 43.07 & 0.31 & 0.41 \\
\hline \multirow[t]{3}{*}{ FLL } & US & 0.66 & 0.38 & 46.89 & 0.22 & 0.57 \\
\hline & MS & 1.02 & 0.51 & 62.04 & 0.39 & 1.03 \\
\hline & $\mathrm{LS}$ & 1.58 & 0.74 & 88.86 & 0.83 & 1.06 \\
\hline \multirow[t]{3}{*}{ OPP } & US & 1.44 & 0.74 & 89.39 & 0.78 & 0.89 \\
\hline & MS & 1.00 & 0.61 & 73.00 & 0.43 & 0.76 \\
\hline & $\mathrm{LS}$ & 1.13 & 0.49 & 58.37 & 0.32 & 1.35 \\
\hline Sig & & 0.54 & 0.58 & 0.59 & 0.23 & 0.72 \\
\hline $\operatorname{LSD}(0.05)$ & & $n s$ & $n s$ & $n s$ & $n s$ & $N s$ \\
\hline $\mathrm{CV}(\%)$ & & 66.12 & 73.17 & 72.87 & 98.08 & 71.41 \\
\hline
\end{tabular}

Note: $i_{0}-$ initial infiltration rate, $i_{\mathrm{f}}$ - final infiltration rate, I - cumulative infiltration, $\mathrm{S}$ - sorptivity, A - transmissivity.

\subsection{Correlations of Soil Properties and Infiltration Characteristics}

Table 7 presents the correlations between some soil properties and infiltration characteristics. Initial infiltration rate correlated significantly and positively with total porosity $(\mathrm{r}=0.620, \mathrm{P} \leq 0.01)$ and saturated hydraulic conductivity $(\mathrm{r}=0.445, \mathrm{P} \leq 0.05)$. The correlation of initial infiltration with bulk density was negative $(\mathrm{r}$ $=-0.620, \mathrm{P} \leq 0.01)$. Final infiltration rate and cumulative infiltration correlated significantly and positively total 
porosity and saturated hydraulic conductivity while their correlations with bulk density were negative Table 3. These results show that infiltration rates were strongly associated with soil structural characteristics.

Sorptivity correlated significantly and positively with total porosity $(r=0.544, \mathrm{P} \leq 0.01)$ because it is the gravity-free, capillary-induced absorption (Clothier \& Scotter, 2002) thus its strong and positive association observed with total porosity, which are the soil "capillary tubes". Sorptivity also had a significant and positive correlation and saturated hydraulic conductivity $(\mathrm{r}=0.430, \mathrm{P} \leq 0.05)$ because they are conceptually related constructs. Sorptivity is an integral soil-water property that contains information about the soil hydraulic conductivity (White \& Perroux, 1987) and the two are not independent variables but the latter is roughly proportional to square of the former (Clothier \& Scotter, 2002). The correlation between sorptivity and bulk density was negative $(r=-0.544, \mathrm{P} \leq 0.01)$. Transmissivity correlated significantly and positively with fine sand $(\mathrm{r}=0.392$, $\mathrm{P} \leq 0.05)$ and mean weight diameter $(\mathrm{r}=0.476, \mathrm{P} \leq 0.01)$. Fine sand (a component of soil texture) and mean weight diameter, (index of soil aggregation) are directly related to soil porosity (Hillel, 2004). These explains the positive correlation between then and transmissivity observed in this study. The significant and positive correlation of transmissivity with fine Transmissivity is a gravity factor, which is due to the impact of pores on the flow of water through soil and is closely related to hydraulic conductivity.

Initial and final infiltration rates, cumulative infiltration and sorptivity showed strong and negative associations with bulk density while their associations with total porosity were strong and positive. This is so because soil pores (large pores) are the conduits through which water passes and also serve as the storage spaces for soil water. Therefore, increase in such conduits and storage spaces must have a direct influence on infiltration while the reverse is obtained when the storage spaces are reduced as shown by an increase in bulk density. Negative correlation of infiltration rates or cumulative infiltration with bulk density had been reported in previous research works (Chen, Yuan, Shao, Wang, \& Mu, 2014; Gebreselassie, Amdemariam, Haile, \& Yamoah, 2009; Ogban \& Utin, 2015; Patle, Sikar, Rawat, \& Singh, 2019).

\subsection{Regression of Cumulative Infiltration with Some Soil Properties}

Simple linear regression of cumulative infiltration with bulk density and saturated hydraulic conductivity were significant $(\mathrm{P} \leq 0.05)$ while the relationships with other soil properties were not significant $(\mathrm{P} \leq 0.05)$ Table 8 . The relationship of cumulative infiltration with bulk density was negative whereas there was a positive relationship with saturated hydraulic conductivity. The negative relationship between bulk density and infiltration agrees with the works of Okon and Osuji (2014); Patle et al. (2019).

\section{CONCLUSION}

This study was aimed at determining the effect of land use and slope position on sandstone in Akwa Ibom State, Nigeria. The study showed that oil palm plantation and fallowed land encouraged the maintenance of soil cover, increased the organic matter content of the soil, reduced bulk density, increased the soil porosity, improved the stability of soils against forces of detachments and transportation as well as increased the infiltration capacity of the soil. Downslope movement of soil particles caused the upper slope region to lose most of its organic matter contents to the middle and lower slope regions. The practice of regular land fallowing and plantation agriculture on sloppy terrains therefore promises to help maximize the benefits of increased water infiltration which is necessary for improved soil health and productivity. Soil management options that encourage heavier input of organic materials in the upper slope soils are advocated. 
International Journal of Sustainable Agricultural Research, 2021, 8(3): 122-133

Table-7. Associations (correlations) between soil properties and infiltration characteristics.

\begin{tabular}{|c|c|c|c|c|c|c|c|c|c|c|c|c|c|c|}
\hline & $i_{0}$ & $i_{\mathrm{f}}$ & I & $\mathbf{S}$ & A & CS & FS & Silt & Clay & BD & TP & MWD & Ksat & OM \\
\hline io & 1.000 & & & & & & & & & & & & & \\
\hline$i_{\mathrm{f}}$ & $0.892^{* * *}$ & 1.000 & & & & & & & & & & & & \\
\hline I & $0.892^{\text {*** }}$ & $1.000^{* * *}$ & 1.000 & & & & & & & & & & & \\
\hline $\mathrm{S}$ & $0.901^{* * *}$ & $0.825^{* *}$ & $0.823^{* *}$ & 1.000 & & & & & & & & & & \\
\hline A & $0.594^{* * *}$ & 0.353 & 0.355 & 0.247 & 1.000 & & & & & & & & & \\
\hline CS & -0.256 & -0.335 & -0.335 & -0.115 & -0.246 & 1.000 & & & & & & & & \\
\hline $\mathrm{FS}$ & 0.186 & 0.243 & 0.251 & 0.008 & $0.392^{*}$ & $-0.755^{* *}$ & 1.000 & & & & & & & \\
\hline Silt & 0.055 & 0.136 & 0.131 & 0.063 & -0.238 & $-0.419^{*}$ & -0.139 & 1.000 & & & & & & \\
\hline Clay & 0.255 & 0.261 & 0.256 & 0.185 & 0.253 & $-0.721^{* *}$ & $0.412^{*}$ & 0.054 & 1.000 & & & & & \\
\hline $\mathrm{BD}$ & $-0.620^{* * *}$ & $-0.658^{* * *}$ & $-0.662^{* * *}$ & $-0.544^{* * *}$ & -0.310 & $.657^{* * *}$ & $-0.555^{* *}$ & -0.131 & $-0.549^{* * *}$ & 1.000 & & & & \\
\hline $\mathrm{TP}$ & $0.620^{* *}$ & $0.658^{* *}$ & $0.662^{* *}$ & $0.544^{* * *}$ & 0.310 & $-0.657^{* *}$ & $0.555^{* *}$ & 0.131 & $0.549^{* * *}$ & $-1.000^{* * *}$ & 1.000 & & & \\
\hline MWD & 0.257 & 0.241 & 0.246 & 0.094 & $0.476^{*}$ & $-0.503^{* *}$ & $0.609^{* *}$ & -0.312 & $0.608^{* * *}$ & $-0.608^{* * *}$ & $0.608^{* *}$ & 1.000 & & \\
\hline Ksat & $0.445^{*}$ & $0.558^{* *}$ & $0.559^{* *}$ & $0.430^{*}$ & 0.231 & $-0.428^{*}$ & $0.510^{* * *}$ & -0.039 & 0.274 & $-0.456^{*}$ & $0.456^{*}$ & $0.448^{*}$ & 1.000 & \\
\hline $\mathrm{OM}$ & 0.270 & 0.272 & 0.269 & 0.181 & 0.304 & $-0.725^{* *}$ & $0.467^{*}$ & -0.003 & $0.991^{* * *}$ & $-0.589^{* * *}$ & $0.589^{* * *}$ & $0.707^{* * *}$ & 0.318 & 1.000 \\
\hline
\end{tabular}

Note: $i_{i}$ - initial infiltration rate, $i_{\mathrm{f}}$ - final infiltration rate, I - cumulative infiltration, S - sorptivity, A - transmissivity, CS - coarse sand, FS - fine sand, BD - bulk density, TP - total porosity, MWD - mean weight diameter, Ksat - saturated hydraulic conductivity, OM - organic matter. 
Table-8. Simple linear regression of cumulative infiltration with some soil properties

\begin{tabular}{|c|c|c|c|c|c|c|}
\hline Dependent Variable & Independent Variable & Intercept & Slope & $\mathbf{R}^{2}$ & $\mathbf{n}$ & $\mathbf{p}$ \\
\hline \multirow{5}{*}{ Cumulative Infiltration } & $\mathrm{CS}$ & 310.1 & -0.407 & 0.112 & 27 & 0.09 \\
\hline & $\mathrm{FS}$ & -4.272 & 0.471 & 0.063 & 27 & 0.21 \\
\hline & Clay & -20.829 & 0.725 & 0.066 & 27 & 0.20 \\
\hline & $\mathrm{BD}$ & 508.386 & -304.278 & 0.438 & 27 & 0.00 \\
\hline & $\mathrm{OM}$ & -22.576 & 27.131 & 0.072 & 27 & 0.18 \\
\hline
\end{tabular}

Note: CS - coarse sand, FS - fine sand, BD - bulk density, MWD - mean weight diameter, Ksat - saturated hydraulic conductivity, OM - organic matter.

Funding: This study received no specific financial support.

Competing Interests: The author declares that there are no conflicts of interests regarding the publication of this paper.

Acknowledgement: Author gratefully acknowledges the staff of the Soil Science Laboratory of the University of Uyo for their support during the laboratory phase of the work.

\section{REFERENCES}

Al-Kaisi, M. (2019). Frequent tillage and its impact on soil quality. USA: Extension Outreach, Iowa State University of Science and Technology.

Blanco, H., \& Lal, R. (2008). Principles of soil conservation and management. USA: Springer Science+Business Media B.V.

Bot, A., \& Benites, J. (2005). The importance of soil organic matter: Key to drought-resistant soil and sustained food production. FAO Land and Plant Nutrition Management Service. Rome: Food and Agriculture Organization of The United Nations.

Carrizo, M. E., Alesso, C. A., Cosentino, D., \& Imhoff, S. (2014). Aggregation agents and structural stability in soils with different texture and organic carbon contents. Scientia Agricola, 72(1), 75-82. Available at: https://doi.org/10.1590/0103-9016-2014-0026.

Cerdia, A. (1996). Seasonal variability of infiltration rates under contrasting slope conditions in southeast Spain. Geoderma, 69(34), 217-232. Available at: https://doi.org/10.1016/0016-7061(95)00062-3.

Chaudhari, P. R., Ahire, D. V., Ahire, V. D., Chkravarty, M., \& Maity, S. (2013). Soil bulk density as related to soil texture, organic matter content and available total nutrients of Coimbatore soil. International Journal of Scientific and Research Publications, 3(2), 1-8.

Chen, L., Yuan, Z., Shao, H., Wang, D., \& Mu, X. (2014). Effects of thinning intensities on soil infiltration and water storage capacity in a Chinese pine-oak mixed forest. The Scientific World Journal, 2014, 1 - 7.

Chenu, C., Le Bissonnais, Y., \& Arrouays, D. (2000). Organic matter influence on clay wettability and soil aggregate stability. Soil Science Society of America Journal, 64(4), 1479-1486. Available at: https://doi.org/10.2 136/sssaj2000.6441479x.

Clothier, B., \& Scotter, D. (2002). Unsaturated water transmission parameters obtained from infiltration. In: Dane, J.H. and Topp, G.C., eds. Methods of soil analysis (pp. 879-898). Madison: Soil Science Society of America.

Cooperband, L. R. (2002). Building soil organic matter with organic amendments: A resource for urban and rural gardeners, small farmers, turfgrass managers and large-scale producers: Center for Integrated Agricultural Systems (CIAS), College of Agricultural and Life Sciences, University of Wisconsin-Madison. Retrieved from: https://cias.wisc.edu/wp-content/uploads/sites/194/2008/07/soilorgmtr 1.pdf.

Dane, J. H., \& Topp, G. C. (2002). Methods of soil analysis. Part 4: Physical methods. Soil Science Society of America Journal, 981983.

Duchicela, J., Vogelsang, K. M., Schultz, P. A., Kaonongbua, W., Middleton, E. L., \& Bever, J. D. (2012). Non-native plants and soil microbes: potential contributors to the consistent reduction in soil aggregate stability caused by the disturbance of North American grasslands. New Phytologist, 196(1), 212-222. Available at: https://doi.org/10.1111/j.14698137.2012.04233.x.

Enwezor, W. O., Udo, E. J., \& Sobulo, R. A. (1981). Fertility status and productivity of the acid sands. In: E. J. Udo and R. A. Sobulo (eds.) Acid Sands of Southern Nigeria. Soil Sci. Soc. Nig. Spec. Publ. Monogr. Series I, 56-73. 
Food and Agriculture Organization. (1979). Soil survey investigations for irrigation. Rome: FAO.

Freeze, R. A., \& Cherry, J. A. (1979). Groundwater (pp. 604). Englewood Cliffs, New Jersey: Prentice-Hall.

Gebreselassie, Y., Amdemariam, T., Haile, M., \& Yamoah, C. (2009). Lessons from upstream soil conservation measures to mitigate soil erosion and its impacts on upstream and downstream users of the Nile River. Paper presented at the In: Proceedings of the Intermediate Results Dissemination Workshop held at the International Livestock Research Institute (ILRI), organized by International Water Management Institute (IWMI), Addis Ababa, Ethiopia.

Gol, C., \& Dengiz, O. (2008). Effect of modifying land cover and long-term agricultural practices on the soil characteristics in native forest-land. Journal of Environmental Biology, 29(5), 667-682.

Guzman, J., \& Al-Kaisi, M. (2011). Landscape position effect on selected soil physical properties of reconstructed prairies in southcentral Iowa. Journal of Soil and Water Conservation, 66(3), 183-191. Available at: https://doi.org/10.2489/jswc.66.3.183.

Hillel, D. (2004). Introduction to environmental soil physics. New York: Academic Press.

Jenny, H. (1994). Factors of soil formation; A system of quantitative pedology. New York: Dover Publications, Inc.

Kemper, W. D., \& Rosenau, R. C. (1986). Aggregate stability and size distribution. In: Klute, A. Ed., Methods of soil analysis. Part 1. Agronomy Monograph 9 (2nd ed., pp. 425-442). Madison, Wisconsin.

Lal, R. (1981). Analyses of different processes governing soil erosion by water in the tropics. Paper presented at the Erosion and Sediment Transport Measurement Proceedings of the Florence Symposium.

Liu, H., Lei, T., Zhao, J., Yuan, C., Fan, Y., \& Qu, L. (2011). Effects of rainfall intensity and antecedent soil water content on soil infiltrability under rainfall conditions using the run off-on-out method. Journal of Hydrology, 396(1-2), 24-32. Available at: https://doi.org/10.1016/j.jhydrol.2010.10.028.

Liu, M., Han, G., Li, Z., Liu, T., Yang, X., Wu, Y., \& Song, Z. (2017). Effects of slope position and land use on the stability of aggregate-associated organic carbon in calcareous soils. Acta Geochimica, 36(3), 456-461. Available at: https://doi.org/10.1007/s1 1631-017-0194-y.

Mbagwu, J. (1995). Testing the goodness of fit of infiltration models for highly permeable soils under different tropical soil management systems. Soil and Tillage Research, 34(3), 199-205. Available at: https://doi.org/10.1016/01671987(95)00463-3.

Moges, A., \& Holden, N. M. (2008). Soil fertility in relation to slope position and agricultural land use: A case study of Umbulo catchment in Southern Ethiopia. Environmental Management, 42(5), 753-763. Available at: https://doi.org/10.1007/s00267-008-9157-8.

Nelson, D. W., \& Sommers, L. E. (1996). Total carbon, organic carbon and organic matter. Madison, WI: Soil Science Society of America.

Ogban, P. I., Obi, J. C., Utin, U. E., Inyang, N. I., Akpan, I. D., \& Etuk, E. J. (2012). Comparison of some infiltration models on sandstone-derived soils in Akwa Ibom State, Southeastern Nigeria. Nigerian Journal of Soil Science, 22(2), 282 - 290.

Ogban, P. I., \& Utin, U. E. (2015). Effect of land use on infiltration characteristics of sandstone-derived soils in Akwa Ibom State, Southeastern Nigeria. Journal of Applied Agricultural Research, 2015(7), 141-149.

Okon, M. A., \& Osuji, G. E. (2014). Differences in infiltration rate under a catenary landscape in Owerri, Southeastern Nigeria. International Journal of Research in Agriculture and Forestry, 1(2), 1- 6.

Osuji, G., Okon, M., Chukwuma, M., \& Nwarie, I. (2010). Infiltration characteristics of soils under selected land use practic es in Owerri, Southeastern Nigeria. World journal of Agricultural sciences, 6(3), 322-326.

Patle, G. T., Sikar, T. T., Rawat, K. S., \& Singh, S. K. (2019). Estimation of infiltration rate from soil properties using regression model for cultivated land. Geology, Ecology, and Landscapes, 3(1), 1-13.

Petters, S. W., Adighije, C. I., Essang, E. B., \& Ekpo, I. E. (1989). A regional hydrogeological study of rural water supply options for planning and implementation of phase II rural water programme in Cross River State, Nigeria. Nigeria: Rept. for Director of Rural Devt. CRSG. 
Philip, J. R. (1957). The theory of infiltration: 4. Sorptivity and algebraic infiltration equations. Soil Science, 84(3), $257-264$. Available at: https://doi.org/10.1097/00010694-195709000-00010.

Portella, C. M. R., Guimarães, M. d. F., Feller, C., Fonseca, I. C. d. B., \& Tavares Filho, J. (2012). Soil aggregation under different management systems. Brazilian Journal of Soil Science, 36(6), 1868-1877.

Rivera, L. D. (2010). Systematic variability of soil hydraulic conductivity across three vertisol catenas. Master of Science Thesis submitted to the Office of Graduate Studies of Texas A\&M University, USA.

Shukla, M., Lal, R., \& Unkefer, P. (2003). Experimental evaluation of infiltration models for different land use and soil management systems. Soil Science, 168(3), 178-191. Available at: https://doi.org/10.1097/01.ss.0000058890.60072.7c.

Singh, B., Sihag, P., \& Singh, D. (2014). Study of infiltration characteristics of locally soils. J Civ Eng Environ Technol, 1(5), 9-13.

Soderberg, M. H. (2015). Measuring soil infiltration rates in cultivated land a case study of Ifakara, Tanzania. MSc Thesis. Department of Physical Geography. Stockholm University.

Turner, E. (2006). Comparison of infiltration equations and their field validation by rainfall simulation. Master of Science Thesis, Faculty of the Graduate School of the University of Maryland, United States of America.

USDA. (2014). Soil bulk density moisture aeration. USA: USDA-NRCS.

USDA. (2014). Soil infiltration. soil Quality kits - Guide for educators. USA: USDA-NRCS.

White, I., \& Perroux, K. M. (1987). Use of sorptivity to determine field soil hydraulic properties. Soil Science Society of America Journal, 51(5), 1093-1101.

Yeshaneh, G. T. (2015). Effect of slope position on soil physico-chemical properties with different management practices in small holder cultivated farms of abuhoy gara catchment, gidan district, North Wollo Gebeyaw. American Journal of Environmental Protion, 3(5), 174-179.

Yimer, F., Messing, I., Ledin, S., \& ABdelkadir, A. (2008). Effects of different land use types on infiltration capacity in a catchment in the highlands of Ethiopia. Soil use and Management, 24(4), 344-349. Available at: https://doi.org/10.1111/j.1475-2743.2008.00182.x.

Youngs, E. G. (1991). Infiltration measurements- A review. Hydrological Processes, 5(3), 309-320.

Views and opinions expressed in this article are the views and opinions of the author(s), International Journal of Sustainable Agricultural Research shall not be responsible or answerable for any loss, damage or liability etc. caused in relation to/arising out of the use of the content. 